\title{
Editorial: Novel Materials for Green Soldering and Brazing
}

\author{
M. A. Fazal ${ }^{1 *}$, Liang Zhang ${ }^{2}$, Xingxing Wang $^{3}$ and Guang Zeng ${ }^{4}$ \\ ${ }^{1}$ Department of Mechanical and Materials Engineering, Faculty of Engineering, University of Jeddah, Jeddah, Saudi Arabia, \\ ${ }^{2}$ School of Mechatronic Engineering, Jiangsu Normal University, Xuzhou, China, ${ }^{3}$ North China University of Water Conservancy \\ and Electric Power, Zhengzhou, China, ${ }^{4}$ Central South University, Changsha, China
}

Keywords: $\mathrm{Pb}$ free solder, Cd-free filler, interconnection, fabrication, electronic devices and packaging

Editorial on the Research Topic

\section{Novel Materials for Green Soldering and Brazing}

In the field of electronics and packaging, $\mathrm{Pb}$ based solder (e.g., $\mathrm{Sn}-\mathrm{Pb}$ ) and $\mathrm{Cd}$ based filler (e.g., Ag$\mathrm{Cu}-\mathrm{Cd}$ ) alloys were popularly used as the most reliable interconnection materials. Traditionally, these alloys were widely used materials for soldering and brazing in the industries of electronic devices and products. However, the RoHS (Restriction of Hazardous Substances) banned both $\mathrm{Pb}$ and $\mathrm{Cd}$ as hazardous to human health due to their toxic behaviors. Banning of such toxic materials has propelled the entire electronic industries for searching alternative and sustainable replacements. At the time of proposing this Research Topic on June 16, 2020, the electronic industries were experiencing a steady increase in the demand for finding viable $\mathrm{Pb}$-free solders and $\mathrm{Cd}$-free filler metals. It is evident that the scientific community must come together to explore sustainable alternatives. In this case, focus must be given on several critical issues including wettability, melting point, cost, availability, strength, corrosion resistance, thermal fatigue, etc. for finding the alternatives to $\mathrm{Pb}$ and $\mathrm{Cd}$ based alloys. In response to this challenge, Frontiers in Materials joined the global scientific community by proposing this Research Topic-"Novel Materials for Green Soldering and Brazing". The present Research Topic thus aimed to highlight a few examples of significant contributions that materials scientists can bring to the global platform. We particularly welcomed contributions that include, but were not limited to, the following topics and their applicants for addressing the problems identified in electronic industries:

- The alloying system of Pb-free solders and $\mathrm{Cd}$-free filler metals and their related processing.

- Fabrication of Pb-free solders and $\mathrm{Cd}$-free filler metals for green soldering and brazing.

- Properties, modeling and applications of Pb-free solders and Cd-free filler metals

- Reliability of Pb-free solder and Cd-free filler materials.

This article was submitted to Environmental Degradation of Materials,

a section of the journal Frontiers in Materials

Received: 26 July 2021 Accepted: 02 August 2021 Published: 08 September 2021

Citation:

Fazal MA, Zhang L, Wang $X$ and Zeng G (2021) Editorial: Novel Materials for Green Soldering and Brazing.

Front. Mater. 8:747312 doi: 10.3389/fmats.2021.747312

Accordingly, this brief themed article collection features four key contributions, as briefly summarized below, reporting precise respective abstracts. It is expected to give an expression and visibility to the interested stockholders with an overview of current research and developments in this sector.

Nur Amirah Mohd Zahri et al., focused on "Deformation and fracture behavior of sandwiched copper foam brazed joint using amorphous copper-tin-nickel-phosphorus filler”. Utilization of open-cell metal foams in functional applications such as in energy absorption, noise absorber, heat insulator and lightweight panels become trending in many industrial application. The development of reliable joining technologies for sandwiched metal foams is crucial for heat e application and one of the technique used is brazing process. In current work, copper foam was sandwiched between copper plate using amorphous filler of $\mathrm{Cu}-9.7 \mathrm{Sn}-5.7 \mathrm{Ni}-7.0 \mathrm{P}$ (Cu-copper, Sn-tin, Ni-nickel, 
P-phosphorus) via brazing technique. The shear test was conducted on the brazed joint interface of copper/copper foam, while the compressive test was carried out on the brazed sample. Microstructures of the copper substrate surface obtained from the shear-fracture of brazed copper/copper foam show tear region and cleavage fractures. The stress-strain curve of shear and compressive explain the deformation behavior of the brazed sample.

Bang Jiang et al., focused on "Microstructure Evolution and Shear Property of Cu-In Transient Liquid Phase Sintering Joints". Transient liquid phase sintering (TLPS) is a promising joining technology that can achieve high-temperature resisted solder joints at low temperature, showing excellent potential in power electronics. In this work, $\mathrm{Cu} / \mathrm{Cu}-\mathrm{In} / \mathrm{Cu}$ solder joints were successfully prepared by TLPS process. The effects of bonding pressure and holding time on the microstructure and shear strength of $\mathrm{Cu}-\mathrm{In}$ TLPS joints at $260^{\circ} \mathrm{C}$ and $320^{\circ} \mathrm{C}$ were studied. The results showed that as bonding pressure increased from 0.1 to $0.6 \mathrm{MPa}$, the porosity decreased and shear strength increased significantly. No obvious change was found as bonding pressure continued to increase to $1 \mathrm{MPa}$. As holding time increased at $260^{\circ} \mathrm{C}, \mathrm{Cu}_{11} \mathrm{In}_{9}$ was formed and gradually transformed to $\mathrm{Cu}_{2} \mathrm{In}$ that can withstand elevated temperature. Meanwhile, the porosity decreased while shear strength increased. It was calculated that volume expansion $(12.74 \%)$ occurred during the phase transition from $\mathrm{Cu}_{11} \mathrm{In}_{9}$ to $\mathrm{Cu}_{2} \mathrm{In}$. When bonding temperature increased to $320^{\circ} \mathrm{C}$, only $\mathrm{Cu}_{2} \mathrm{In}$ was detected and then gradually transformed to $\mathrm{Cu}_{7} \mathrm{In}_{3}$ with the growing holding time. As holding time reached $120 \mathrm{~min}$, their porosity increased and lead to weak shear strength due to volume shrinkage $(15.43 \%)$ during the phase transition from $\mathrm{Cu}_{2}$ In to $\mathrm{Cu}_{7} \mathrm{In}_{3}$.

Liang Zhang and Su-Juan Zhong focused on "Effect of $\mathrm{Ni}_{3} \mathrm{Sn}_{4}$ on the thermomechanical fatigue life of solder joints in 3D IC". In this paper, $\mathrm{Ni} / \mathrm{Sn} / \mathrm{Ni}$ joints simulated the $3 \mathrm{D}$ integration was carried out by TLP bonding $\left(250^{\circ} \mathrm{C}, 0.2 \mathrm{~N}\right)$ with different bonding time. After TLP bonding, planner-type Ni3Sn4 IMC can be observed, when the bonding time is $180 \mathrm{~min}$, complete Ni3Sn4 can be found. The diffusion coefficient $\mathrm{D}$ can be determined to be $32.4 \mu \mathrm{m}^{2} / \mathrm{min}$. Based on finite element simulation, it is demonstrated that the shear stress and creep strain increases obviously with the increase of IMC thickness, the results calculated show that the IMC thickness can impact the fatigue life of solder joints significantly, with the increase the $\mathrm{Ni}_{3} \mathrm{Sn}_{4}$ thickness, the fatigue life of solder joints can be decreased obviously.

Deku Zhang et al., focused on "Effect of vacuum heat treatment on microstructures and mechanical properties of 7A52 aluminum alloy- $\mathrm{Al}_{2} \mathrm{O}_{3}$ ceramic brazed joints". This study investigated the interface morphology, microstructure composition and connection strength of 7A52 aluminum alloy- $\mathrm{Al}_{2} \mathrm{O}_{3}$ ceramic brazed joints under heat treatment conditions. Alumina ceramics were first treated with electroless nickel plating, followed by vacuum heat treatment at different temperatures. Then an Al-Si-Mg intermediate layer was placed between the treated alumina ceramic and 7A52 aluminum alloy for brazing under the conditions of welding temperature $590^{\circ} \mathrm{C}$, holding time $1 \mathrm{~h}$, pressure $2 \mathrm{MPa}$. Results showed that when heat treatment was performed at $350^{\circ} \mathrm{C}$ and below, the nickel-plated metal had an amorphous structure, and when performed at $400^{\circ} \mathrm{C}$, the nickel-plated layer had a crystalline structure and the brittle phase $\mathrm{Ni}_{3} \mathrm{P}$ was precipitated. When the heat treatment temperature was $350^{\circ} \mathrm{C}$, the joint shear strength reached the maximum, which was $68.7 \mathrm{MPa}$.

\section{AUTHOR CONTRIBUTIONS}

MF wrote the first draft of the manuscript. All authors contributed to the manuscript revision, read and approved the submitted version.

Conflict of Interest: The authors declare that the research was conducted in the absence of any commercial or financial relationships that could be construed as a potential conflict of interest.

Publisher's Note: All claims expressed in this article are solely those of the authors and do not necessarily represent those of their affiliated organizations, or those of the publisher, the editors and the reviewers. Any product that may be evaluated in this article, or claim that may be made by its manufacturer, is not guaranteed or endorsed by the publisher.

Copyright (c) 2021 Fazal, Zhang, Wang and Zeng. This is an open-access article distributed under the terms of the Creative Commons Attribution License (CC BY). The use, distribution or reproduction in other forums is permitted, provided the original author(s) and the copyright owner(s) are credited and that the original publication in this journal is cited, in accordance with accepted academic practice. No use, distribution or reproduction is permitted which does not comply with these terms. 